\title{
Structural performance evaluation of historical landmark (Yokufu-en) built in the Taisho period
}

\author{
S. Nagashima ${ }^{1}$, M. Mochizuki ${ }^{1}$, M. Suzuki ${ }^{1}$, T. Ninomiya ${ }^{1}$, \\ R. Tamura ${ }^{1}$, T. Nakano ${ }^{2} \&$ M. Kinoshita ${ }^{2}$ \\ ${ }^{I}$ NTT Facilities, Inc., Japan \\ ${ }^{2}$ NTT Facilities Research Institute Inc., Japan
}

\begin{abstract}
The main building of Yokufu-en has been designated as a "Selected Historical Building of Tokyo Metropolitan Government," built after the 1923 Great Kanto Earthquake in the Taisho period. This building was designed by Yoshikazu Uchida, a famous university professor and his assistant. As a result of the study, the building has enough strength of structure, and the concrete shows sufficient compressive strength. However, as the 3rd story has a high eccentric factor it is necessary to be reinforced for earthquake resistance. The reinforcement plan was designed for obtaining a prescribed seismic capacity performance in Japan.
\end{abstract}

Keywords: seismic evaluation, historical-landmark, structural performance evaluation, Yoshikazu Uchida.

\section{Introduction}

The main building of Yokufu-en (the main building of current Yokufukai, a social welfare corporation) reported in this paper was a hospital which was built to protect people who were affected by the 1923 Great Kanto Earthquake. It was designed by Yoshikazu Uchida and his assistant Tatuto Toki in 1925 and completed in 1926 [1]. It is a valuable building designated as a "Selected Historical Building of Tokyo Metropolitan Government" in 2001. The building is currently used as offices. Structural and seismic evaluations were conducted to check its seismic capacity. This paper reports the details of the technical data used when the building was designed including the Urban Building Law, and the 
structural and seismic evaluation results of the building for the structural performance of this historical landmark designed and constructed in the Taisho period.

\section{Outline of the building}

Location
Application
Designed
Total floor area
No. of story
Structural classification
Structural type
Foundation type
Design
Construction

: Tokyo

: Offices (original design: hospital rooms, offices)

: 1925 (Completed: 1926)

$: 1,708 \mathrm{~m}^{2}$

: 3 above ground, 1 below ground, 3-story $\mathrm{PH}$

: Reinforced concrete structure

: Rigid-frame structure with seismic resisting walls

: Spread foundation

: Yoshikazu Uchida, Tatuto Toki

: Obayashi Corporation, Nakamura Koumusyo

Elevators were installed in this building in 1995, and part of the exterior wall was repaired in 2005. The building has not been affected by severe natural disasters since its completion. Figure 1 shows a representative elevation and Figure 2 shows a plan of the representative floor. Its tiled exterior walls have been repaired, and part of the surface of the interior wall has been repaired and repainted. Though exposed reinforcing steel was found under part of the eave during appearance and crack check, no obvious cracks, rust on reinforcing steel, or rust fluid were found.

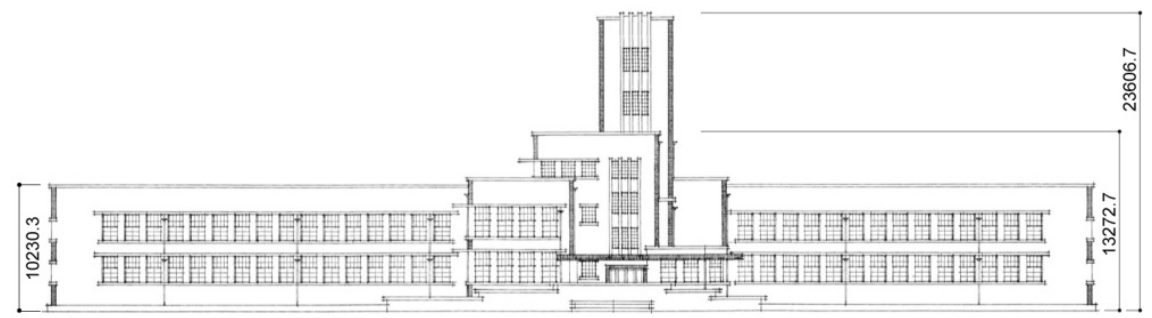

Figure 1: Elevation of the north side.

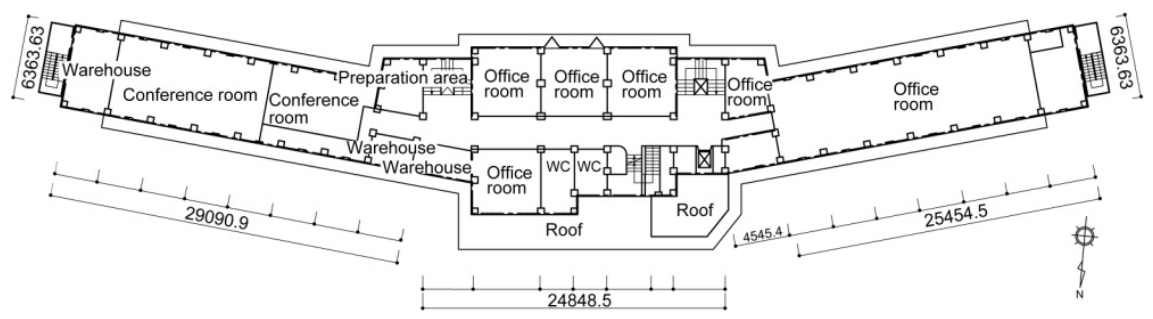

Figure 2: Plan of the representative floor. 


\section{Structural performance evaluation of concrete and reinforcing steels}

\subsection{Physical test of concrete}

The physical test of concrete was conducted using core samples. Each of the samples (12 in total) was collected from the inside of each room. Table 1 shows where the samples were collected and the results of the compressive strength test. The concrete strength test was conducted in accordance with JIS A 1107 (Japanese Industrial Standard). The corrected compressive strength of the samples is obtained by obtaining the correction factor from the ratio between the height and the average diameter, dividing the largest compressive force by the area, and multiplying the value by the correction factor. The average value of all data is $29.9 \mathrm{~N} / \mathrm{mm}^{2}$, and that for above ground is $30.7 \mathrm{~N} / \mathrm{mm}^{2}$. The standard deviations are shown in Table 1 . Though the values differ slightly, the strength would be sufficient for Japanese standard for seismic evaluation.

Table 1: $\quad$ Results of concrete compressive strength test.

\begin{tabular}{|c|c|c|c|c|c|}
\hline Code & Floor & Portion & Room name & $\begin{array}{c}\text { Corrected } \\
\text { compressive } \\
\text { strength } \\
\left(\mathrm{N} / \mathrm{mm}^{2}\right)\end{array}$ & $\begin{array}{l}\text { Standard } \\
\text { deviation } \\
\left(\mathrm{N} / \mathrm{mm}^{2}\right)\end{array}$ \\
\hline B1-1 & 1st basement level & Wall & Dry area & 30.1 & \multirow{3}{*}{4.4} \\
\hline B1-2 & 1st basement level & Wall & $\begin{array}{c}\text { Elevator } \\
\text { machine room }\end{array}$ & 29.5 & \\
\hline B1-3 & 1st basement level & Wall & Staircase & 22.2 & \\
\hline $1-1$ & 1st floor & Wall & Warehouse & 24.5 & \multirow{3}{*}{4.6} \\
\hline $1-2$ & 1st floor & Wall & Staircase & 32.1 & \\
\hline $1-3$ & 1st floor & Wall & $\begin{array}{l}\text { Conference } \\
\text { room }\end{array}$ & 32.8 & \\
\hline $2-1$ & 2nd floor & Wall & Warehouse & 41.9 & \multirow{3}{*}{8.1} \\
\hline $2-2$ & 2nd floor & Wall & Warehouse & 32.4 & \\
\hline $2-3$ & 2nd floor & Wall & Corridor & 25.7 & \\
\hline $3-1$ & 3rd floor & Wall & Stairs & 31.2 & \multirow{3}{*}{1.9} \\
\hline $3-2$ & 3rd floor & Wall & Book room & 28.0 & \\
\hline $3-3$ & 3rd floor & Wall & Book room & 27.9 & \\
\hline
\end{tabular}

\subsection{Reinforcing steel strength test}

One reinforcing steel sample was collected from the interior wall of the warehouse on the 3rd floor. Table 2 shows the results of the tensile strength test. It also shows the comparison with the provisions of the Urban Building Law revised in 1924 and the current JIS (Japanese Industrial Standard). This building satisfies the standard for the reinforcing steel under the Urban Building Law when it was designed. While the tensile strength is slightly lower than the standard value specified under the current JIS, the yield point and the elongation are SR235 (JIS) level. 
738 Structural Repairs and Maintenance of Heritage Architecture XII

Table 2: $\quad$ Results of reinforcing steel tensile strength test.

\begin{tabular}{|c|c|c|c|c|}
\hline Standard & Diameter & $\begin{array}{c}\text { Yield point } \\
\left(\mathrm{N} / \mathrm{mm}^{2}\right)\end{array}$ & $\begin{array}{c}\text { Tensile strength } \\
\left(\mathrm{N} / \mathrm{mm}^{2}\right)\end{array}$ & $\begin{array}{c}\text { Elongation } \\
(\%)\end{array}$ \\
\hline $\begin{array}{c}\text { Measured } \\
\text { value }\end{array}$ & $\begin{array}{c}10 \varphi \\
(9.64 \mathrm{~mm})\end{array}$ & 318 & 367 & 37 \\
\hline $\begin{array}{c}\text { Urban } \\
\text { Building Law }\end{array}$ & $10 \varphi$ & No specification. & 353 & 20 or more \\
\hline $\begin{array}{c}\text { JIS standard } \\
\text { SR235 }\end{array}$ & $10 \varphi$ & 235 or more & 380 to 520 & 20 or more \\
\hline
\end{tabular}

\section{Consideration of the Urban Building Law when the building was designed and the concrete mix}

A bill of architecture was created from the end of the Meiji period to the beginning of the Taisho period. It was finally promulgated as the Urban Building Law in April 1919, and took effect in December 1920 [2]. Yoshikazu Uchida, the designer of the main building of Yokufukai, made a great contribution to the draft of the law. Following the 1923 Great Kanto Earthquake, the provisions of the law relating to structures were revised and the seismic coefficient method was introduced in 1924. It is estimated that the structural design for the main building of Yokufukai designed in 1925 incorporated the contents. The outline of the structural provisions under the Urban Building Law when the building was designed is described below. The Urban Building Law is referred to as "Urban Law" and the Building Standards Law is referred to as "Standards Law" for short. Both SI units and original units are used in comparison. Those for the reinforcing steels are shown in Section 3.2.

\subsection{Design live load}

Table 3 shows comparison of design live load. When the long-term stress is examined, the live load according to the present usage is lower than the design live load defined when the building was designed.

Table 3: $\quad$ Comparison of design live load.

\begin{tabular}{|c|c|r|r|c|c|c|}
\hline \multirow{2}{*}{ Law } & \multirow{2}{*}{ Applications } & \multirow{2}{*}{$\begin{array}{c}\text { S For } \\
\text { slabs }\end{array}$} & \multirow{2}{*}{$\begin{array}{c}\text { B For } \\
\text { beams }\end{array}$} & \multicolumn{2}{|c|}{ R For rigid-frames } & \multirow{2}{*}{\begin{tabular}{c} 
E For \\
\cline { 4 - 5 }
\end{tabular}} \\
\cline { 5 - 6 } & & Girders & Column & earthquakes \\
\hline Urban & Offices, & 370 & 333 & 296 & 259 & - \\
Law & hospital rooms & 3628 & 3266 & 2903 & 2540 & (no defined) \\
\hline Standards & \multirow{2}{*}{ Offices } & 300 & 300 & \multicolumn{2}{|c|}{180} & 80 \\
Law & 2900 & 2900 & \multicolumn{2}{|c|}{1800} & 800 \\
\hline
\end{tabular}

Upper: $\left(\mathrm{kgf} / \mathrm{m}^{2}\right)$; Lower: $\left(\mathrm{N} / \mathrm{m}^{2}\right)$.

\subsection{Concrete mix}

It is estimated that concrete which "passed the provisions for the Portland cement test method set forth in the announcement No. 485 of the Agriculture and 
Commerce Ministry" was used from the description of the enforcement regulations for the Urban Law, and that the mix was "cement 1: sand 2: gravel or crushed stone: 4" by volume ratio. However, the water-cement ratio was not set forth in the Enforcement regulations for the Urban Law, and therefore, the Architectural Institute of Japan issued the "Concrete and reinforcing steel concrete standard specification" in 1929 and the "Standard for Structural Calculation of Reinforced Concrete Structures" (RC standard) [3] in 1933 in the form of rules and guidelines. However, the relationship between concrete strength and water-cement ratio has already been known academically, Journal of Architecture and Building Science reported that the water volume greatly affects concrete properties [4].

The concrete for the building above ground was placed between March and May. The average temperature in Tokyo in those days was 6 deg $\mathrm{C}$ to $20 \mathrm{deg} \mathrm{C}$ and the average humidity was 60 to $80 \%$, which were relatively favourable for concrete placement and curing. In addition, the involvement of top-class Japanese engineers at the time also contributed to the strength to increase. The long-term strength of ordinary concrete using normal Portland cement tends to increase in proportion to the 28-day strength under climate conditions close to those mentioned above [5,6], which could have also improved the strength. Table 4 shows the concrete mix and the allowable stress set forth under the Urban Law in those days.

Table 4: $\quad$ Stress intensity of concrete set forth under the Urban Building Law.

\begin{tabular}{|c|c|c|c|}
\hline Type & Resistant pressure & Resistant tension & $\begin{array}{c}\text { Resistant shear } \\
\text { force }\end{array}$ \\
\hline Concrete & 45 & 4.5 & 4.5 \\
(Material ratio $=1: 2: 4)$ & 4.4 & 0.44 & 0.44 \\
\hline Concrete & 30 & 3.0 & 3.0 \\
(Material ratio = 1:3:6) & 2.9 & 0.29 & 0.29 \\
\hline
\end{tabular}

The material ratio is the ratio among cement: sand: gravel (crushed stone). Upper: $\left(\mathrm{kgf} / \mathrm{cm}^{2}\right)$; Lower: $\left(\mathrm{N} / \mathrm{mm}^{2}\right)$.

\section{Results of neutralization test}

\subsection{Results of neutralization test}

The locations of the neutralization test were the same as those for the concrete compressive strength test. The test results are shown in Table 5. The warehouse on the 1st floor (1-1) had the largest depth of $61 \mathrm{~mm}$, but it is approximately 30 to $40 \mathrm{~mm}$ as a whole. The entire average is $32.5 \mathrm{~mm}$, and the average value above ground is $34.5 \mathrm{~mm}$. Based on this, it is estimated that the neutralization nearly progresses to the position of the reinforcing steel. 
Table 5: $\quad$ Results of neutralization test.

\begin{tabular}{|c|c|c|c|c|c|}
\hline Code & $\begin{array}{c}\text { Average } \\
\text { neutralization } \\
\text { depth }(\mathrm{mm})\end{array}$ & $\begin{array}{c}\text { Standard } \\
\text { deviation } \\
(\mathrm{mm})\end{array}$ & Code & $\begin{array}{c}\text { Average } \\
\text { neutralization } \\
\text { depth }(\mathrm{mm})\end{array}$ & $\begin{array}{c}\text { Standard } \\
\text { deviation } \\
(\mathrm{mm})\end{array}$ \\
\hline B1-1 & 34.1 & 5.9 & $2-1$ & 29.6 & 6.2 \\
\hline B1-2 & 15.4 & 6.8 & $2-2$ & 29.3 & 3.0 \\
\hline B1-3 & 30.3 & 10.6 & $2-3$ & 28.4 & 2.2 \\
\hline $1-1$ & 54.6 & 4.9 & $3-1$ & 32.1 & 2.3 \\
\hline $1-2$ & 23.6 & 2.6 & $3-2$ & 31.7 & 4.4 \\
\hline $1-3$ & 39.1 & 0.9 & $3-3$ & 41.7 & 4.9 \\
\hline
\end{tabular}

\subsection{Neutralization curve created from the estimated water-cement ratio}

The water-cement ratio estimated from the references in 4.2 and the background of the designer is approximately 0.6. Figure 3 shows the neutralization curve calculated from the Kishitani formula [7] based on the value and the measured values. The neutralization ratio was set at 1.0. Though there are large variations, the rate of neutralization calculated from the estimated water-cement ratio and the average value show a similar response. As reference data, data of two school buildings which were completed in the same period shown in the reference [8] were plotted. (K: Completed in 1925; W: Completed in 1932)

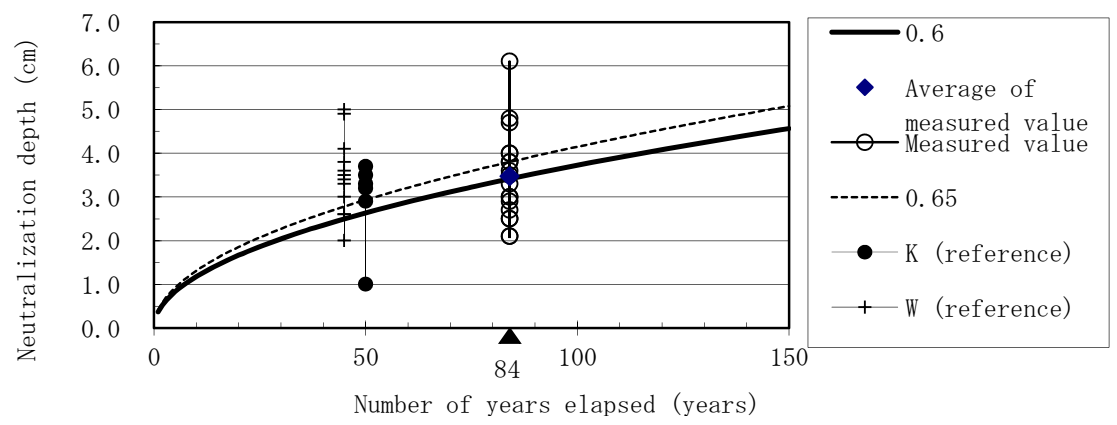

Figure 3: Comparison of measured and calculated neutralization depth.

\section{Results of seismic evaluation}

\subsection{Reinforcing steels}

The intervals of bar arrangement were surveyed using the electromagnetic radar system. The bar arrangement was surveyed using 22 columns on the 1 st and the 2nd floors. As a result, the authors confirmed that the number of main reinforcement of columns corresponded to the drawing created during the design. The intervals of measurement of the shear reinforcement were $191.2 \mathrm{~mm}$ on average, and the largest displacement was within $20 \mathrm{~mm}$. The intervals used for the calculation were set at $200 \mathrm{~mm}$. Figure 4 to Figure 6 show the drawings used 
during design. The cross-section chart (Figure 4) only shows the number of windings of shear reinforcement. The detailed structural drawing (Figure 5) shows the number of windings and the intervals. In the drawing, the top and the bottom of the columns are indicated with the number of windings as @0.40 (Shaku) (approx. $121 \mathrm{~mm}$ ), and the center of the column as @0.60 (Shaku) (approx. $182 \mathrm{~mm}$ ). However, there was no clear agreement between the crosssection chart (Figure 4) and the number in the detailed structural drawing (Figure 5). For this reason, results of the radar survey were used for column shear reinforcement.
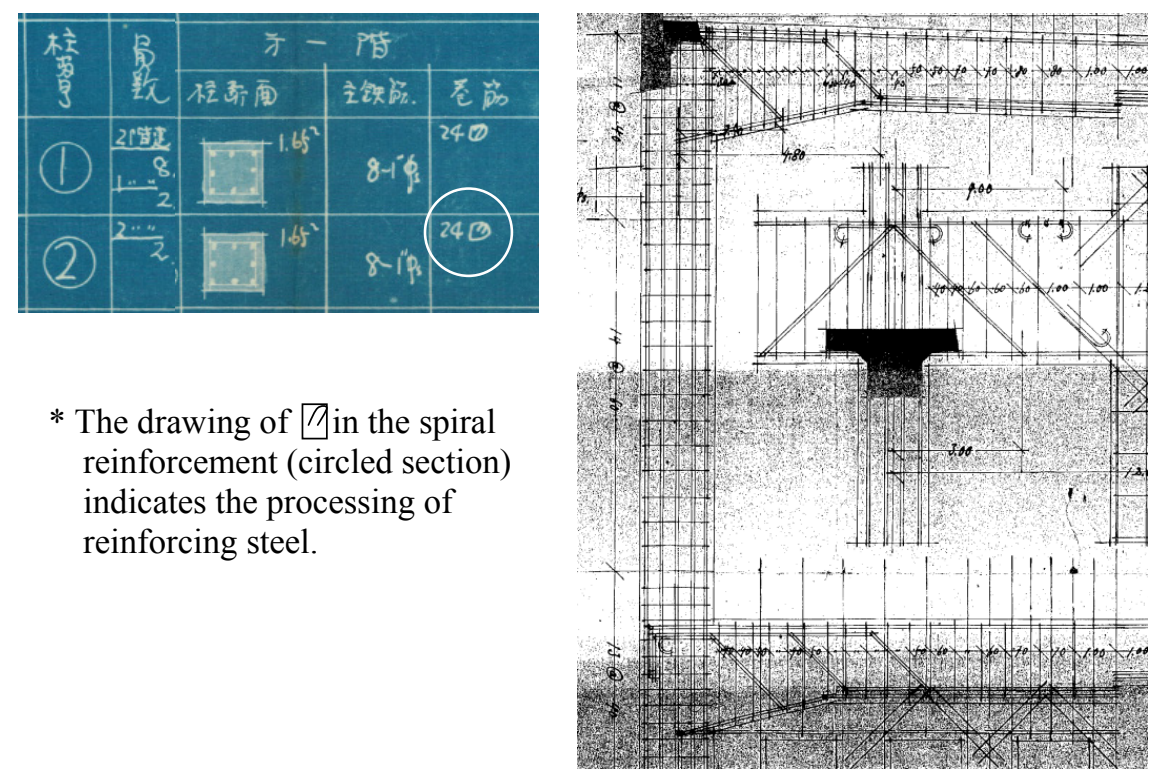

* The drawing of $\emptyset$ in the spiral reinforcement (circled section) indicates the processing of reinforcing steel.

Figure 4: Cross-section chart. Figure 5: Detailed structural drawing.

For hook shape at the edge of the column shear reinforcement, the figure shows a 135-deg hook (Figure 4). Estimating from the background of architectural engineers, the authors determined that the building was constructed in accordance with the drawing and that the 135-deg hook was used. Several years later, Article 36 of the "Reinforcing steel concrete standard specification" [3] in 1933 specified that the folding of the terminal of joining reinforcement (shear reinforcement) should be $135 \mathrm{deg}$ or more.

Since wall bar arrangement is not found in any drawing, it was determined to be $300 \mathrm{~mm}$ pitches with a staggered bar arrangement from the results of actual measurement. The diameter of the wall reinforcement was determined to be $9 \varphi$.

For fixing of beam main reinforcement, the detailed beam main reinforcement structure drawing of Figure 6 shows that the top reinforcement exceeds the center of the column and that the bottom reinforcement is folded about $30 \mathrm{~cm}$ near the center of the column. Since the smallest column width is approx. $50 \mathrm{~cm}$ 


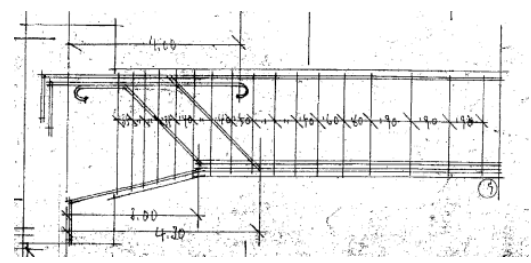

Figure 6: Detailed structural drawing of beam main reinforcement.

and the main reinforcement diameter is $3 / 4$ inch (approx. $19 \mathrm{~mm}$ ), the anchorage length is $29 \mathrm{~d}$ or more from the column surface.

Table 6 shows comparison between the structural provisions set forth in the then Urban Building Law (after revised i $\mathrm{n} \mathrm{1924),} \mathrm{the} \mathrm{description} \mathrm{in} \mathrm{design}$ drawings (structural drawings), and the provisions set forth under the present Building Standards Law. The drawings satisfy the structural provisions after revised in 1924.

Table 6: Comparison between the structural provisions and the drawings.

\begin{tabular}{|c|c|c|c|}
\hline & $\begin{array}{c}\text { Drawing } \\
\text { (comparison with the Urban Law) }\end{array}$ & $\begin{array}{c}\text { Urban Law } \\
\text { (after revised in 1924) }\end{array}$ & $\begin{array}{l}\text { Standards Law } \\
\text { (current rules) }\end{array}$ \\
\hline $\begin{array}{l}\text { Fixing of } \\
\text { reinforcing } \\
\text { steel }\end{array}$ & $\begin{array}{l}\text { Beam top: Fixed exceeding the } \\
\text { column center } \\
\text { Beam bottom: Fixed at the } \\
\text { column center. }\end{array}$ & $\begin{array}{l}\text { Fastening of the terminal to } \\
\text { other structures or fixing by } \\
\text { folding the terminal. }\end{array}$ & $\begin{array}{l}\text { Designation of the } \\
\text { terminal position to start } \\
\text { folding for fixing } \\
\text { Terminal of round bar, } \\
\text { with hook }\end{array}$ \\
\hline $\begin{array}{l}\text { Joint } \\
\text { length of } \\
\text { main } \\
\text { reinforcem } \\
\text { ent }\end{array}$ & $\begin{array}{l}\text { Beams satisfy the standards from } \\
\text { the structural drawing (Diameter } \\
\text { of beam main reinforcement: } \\
19 \varphi \text { ) } \\
\text { Columns were checked from the } \\
\text { photo taken during construction. }\end{array}$ & $\begin{array}{l}25 \mathrm{D} \text { or more of the main } \\
\text { reinforcement diameter }\end{array}$ & $\begin{array}{l}\text { Tensile reinforcement of } \\
\text { the beam for fixing the } \\
\text { column: 40D or more } \\
\text { Location with small } \\
\text { tension: } 25 \mathrm{D} \text { or more }\end{array}$ \\
\hline $\begin{array}{l}\text { Beam } \\
\text { shear } \\
\text { reinforcem } \\
\text { ent }\end{array}$ & $\begin{array}{l}\text { The largest interval is } 1 \text { Shaku } \\
(303 \mathrm{~mm}) \text { with the beam center } \\
\text { depth of } 500 \mathrm{~mm} \text {, which satisfies } \\
\text { the Urban Law. }\end{array}$ & $\begin{array}{l}\text { Placement of binding } \\
\text { reinforcement } \\
\text { Intervals of binding } \\
\text { reinforcement: } 2 / 3 \mathrm{D} \text { or } \\
\text { below }\end{array}$ & $\begin{array}{l}\text { Beam: Stirrup } \\
\text { reinforcement 3/4D or } \\
\text { below }\end{array}$ \\
\hline $\begin{array}{c}\text { Beam } \\
\text { reinforcing } \\
\text { steel }\end{array}$ & Double reinforcement & $\begin{array}{l}\text { Placement of double } \\
\text { reinforcement }\end{array}$ & $\begin{array}{l}\text { Placement of double } \\
\text { reinforcement }\end{array}$ \\
\hline \multirow{4}{*}{$\begin{array}{l}\text { Column } \\
\text { structure }\end{array}$} & 8 to 16 columns & $\begin{array}{l}4 \text { or more main } \\
\text { reinforcement }\end{array}$ & $\begin{array}{l}4 \text { or more main } \\
\text { reinforcement }\end{array}$ \\
\hline & $\begin{array}{l}\text { The reinforcing steel area of all } \\
\text { the columns covers } 1 / 80 \text { or more } \\
\text { of the column area. (Column } \\
\text { main reinforcement diameter: } \\
25 \varphi \text { ) }\end{array}$ & $\begin{array}{l}1 / 80(1.25 \%) \text { or more of the } \\
\text { concrete cross-section area }\end{array}$ & $\begin{array}{l}0.8 \% \text { or more of the } \\
\text { concrete cross-section }\end{array}$ \\
\hline & $\begin{array}{c}\text { Indication of the number of } \\
\text { windings (Average of measured } \\
\text { value: } 191.2 \mathrm{~mm} \text { ) }\end{array}$ & $\begin{array}{l}\text { Intervals of binding } \\
\text { reinforcement are } 1 \text { Shaku } \\
(303 \mathrm{~mm}) \text { or below and less } \\
\text { than } 15 \text { times the main } \\
\text { reinforcement diameter }\end{array}$ & $\begin{array}{c}10 \mathrm{~cm} \text { for column } \\
\text { top/base }(15 \mathrm{~cm} \text { for } \\
\text { others) and less than } 15 \\
\text { times the thin main } \\
\text { reinforcement diameter } \\
\text { Hoop reinforcement ratio: } \\
0.2 \% \text { or more }\end{array}$ \\
\hline & $\begin{array}{l}\text { All the columns satisfy the } \\
\text { standards. }\end{array}$ & $\begin{array}{l}\text { Column small diameter: } \\
1 / 15 \text { or more of the major } \\
\text { spans }\end{array}$ & $\begin{array}{l}\text { Column small diameter: } \\
1 / 15 \text { or more of the major } \\
\text { spans }\end{array}$ \\
\hline
\end{tabular}




\subsection{Results of seismic evaluation}

Based on the results of the field survey and the material test, the Standard for Seismic Evaluation of Existing Reinforced Concrete Buildings, 2001 (The Japan Building Disaster Prevention Association) were used to create seismic evaluation and reinforcement plan. From the average value above ground obtained from the results of the concrete compressive strength test (see 3.1), the concrete strength for calculation was set to Fc28. For reinforcing steels, though the tensile strength is slightly lower than the JIS standard, the yield point and the elongation are satisfied. Therefore, they were set to SR235.

The entire building was evaluated as a six-layer building because the proportion of the 4th or higher floors, which are the penthouse, is large when compared with the 3rd floor in terms of both the area and the weight. The building weight by unit area is larger than that of ordinary buildings (Table 7), which is caused by relatively small spans, a high proportion of exterior walls due to the wing-shaped form, the exterior walls finished with brick-like scratch tiles, and other factors.

Table 7: $\quad$ Area and weight of each floor.

\begin{tabular}{|c|c|c|c|c|c|}
\hline Floor & $\begin{array}{c}\text { Floor area of } \\
\text { each floor } \\
\mathrm{Af}\left(\mathrm{m}^{2}\right)\end{array}$ & $\begin{array}{c}\text { Total floor } \\
\text { area } \\
\Sigma \mathrm{Af}\left(\mathrm{m}^{2}\right)\end{array}$ & $\begin{array}{c}\text { Total weight } \\
\Sigma \mathrm{W}(\mathrm{kN})\end{array}$ & $\begin{array}{c}\text { Unit weight } \\
\mathrm{w}_{2}\left(\mathrm{kN} / \mathrm{m}^{2}\right)\end{array}$ & $\mathrm{Ai}$ \\
\hline $6(\mathrm{PH} 3)$ & 26.5 & 26.5 & 467 & 17.7 & 3.16 \\
\hline $5(\mathrm{PH} 2)$ & 26.5 & 52.9 & 1016 & 19.2 & 2.45 \\
\hline $4(\mathrm{PH} 1)$ & 26.5 & 79.4 & 1623 & 20.5 & 2.14 \\
\hline 3 & 114.4 & 193.8 & 3460 & 17.9 & 1.75 \\
\hline 2 & 739.5 & 933.3 & 13145 & 14.1 & 1.25 \\
\hline 1 & 785.4 & 1718.7 & 24692 & 14.4 & 1.00 \\
\hline
\end{tabular}

PH: Penthouse.

Figure 7 to Figure 9 show framing plans and framing elevations of representative sections. Most of the wing-shaped sections (AX1 - AX8, CX1 CX8) have a rigid-frame structure, but seismic resisting walls are provided to the terminal in both $\mathrm{X}$ and $\mathrm{Y}$ directions. The core area at the center of the building has frames with seismic resisting walls around the corridor and room boundaries.

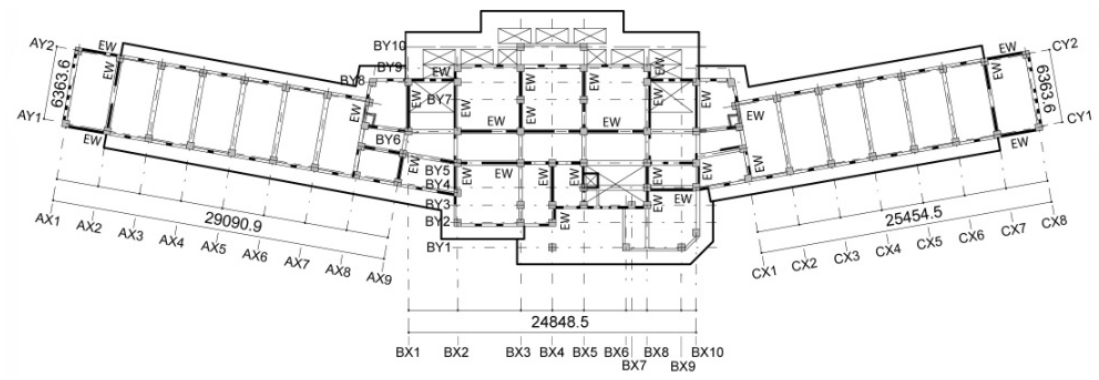

Figure 7: $\quad$ 2nd floor framing plan (EW indicates seismic resisting walls). 
744 Structural Repairs and Maintenance of Heritage Architecture XII

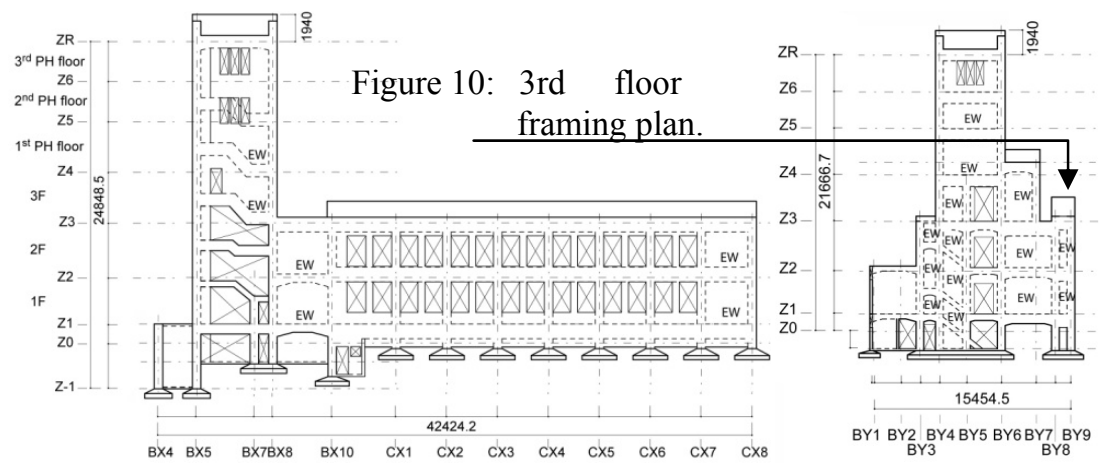

Figure 8: BY4-CY1 framing Figure 9: BX5 framing elevation. elevation.

The aging index was set at 0.927 based on the results of the field survey. No structural cracks were found during the appearance check. From the progress of neutralization, the neutralization range was set to $1 / 3$ or more of the total members. Though no rust fluid or expansion cracks were found in the corrosion of the reinforcing steels, they were set below $1 / 9$ of the members taking neutralization into consideration.

The seismic evaluation results show that all the floors except the 3rd satisfy the Is value: 0.6 or more and $\mathrm{C}_{\mathrm{TU}} \cdot \mathrm{S}_{\mathrm{D}}$ : 0.3 or more (Table 8 ). Spans are small, and the entire building is relatively rigid. Many vertical members have the Fvalue of 1.0, indicating that the building is resistant to earthquakes with its strong structure. Since the design seismic intensity when the building was designed was 0.1 common to every floor, and was not specified for the penthouse, which was set according to necessity, higher floors see more difficulty compared with the

Table 8: $\quad$ Seismic evaluation results (present condition).

\begin{tabular}{|c|c|c|c|c|c|c|c|c|}
\hline & Floor & $\mathrm{C}$ & $\mathrm{F}$ & $\mathrm{E}_{0}$ & $\mathrm{~S}_{\mathrm{D}}$ & $\mathrm{I}_{\mathrm{S}}$ & $\mathrm{C}_{\mathrm{TU}}, \mathrm{S}_{\mathrm{D}}$ & Evaluation \\
\hline \multirow{7}{*}{$\begin{array}{c}\mathrm{X} \\
\text { direction }\end{array}$} & $6(\mathrm{PH} 3)$ & 6.03 & 1.00 & 1.61 & 0.95 & 1.42 & 1.53 & $\mathrm{OK}$ \\
\hline & 5 (PH2) & 5.10 & 1.00 & 1.79 & 0.95 & 1.57 & 1.70 & $\mathrm{OK}$ \\
\hline & 4 (PH1) & 2.33 & 1.00 & 0.95 & 0.95 & 0.83 & 0.90 & $\mathrm{OK}$ \\
\hline & 3 & 1.59 & 1.00 & 0.81 & 0.63 & 0.47 & 0.51 & $\underline{\mathrm{NG}}$ \\
\hline & 2 & 2.41 & 1.00 & 1.83 & 0.95 & 1.61 & 1.74 & OK \\
\hline & 1 & 1.58 & 1.00 & 1.58 & 0.95 & 1.39 & 1.50 & $\mathrm{OK}$ \\
\hline & Floor & $\mathrm{C}$ & $\mathrm{F}$ & $\mathrm{E}_{0}$ & $\mathrm{~S}_{\mathrm{D}}$ & $\mathrm{I}_{\mathrm{S}}$ & $\mathrm{C}_{\mathrm{TU}}, \mathrm{S}_{\mathrm{D}}$ & Evaluation \\
\hline \multirow{6}{*}{$\begin{array}{c}\mathrm{Y} \\
\text { direction }\end{array}$} & 6 (PH3) & 5.18 & 1.00 & 1.38 & 0.95 & 1.22 & 1.31 & OK \\
\hline & $5(\mathrm{PH} 2)$ & 5.56 & 1.00 & 1.95 & 0.95 & 1.72 & 1.85 & $\mathrm{OK}$ \\
\hline & 4 (PH1) & 3.24 & 1.00 & 1.32 & 0.95 & 1.16 & 1.25 & $\mathrm{OK}$ \\
\hline & 3 & 1.76 & 1.00 & 0.89 & 0.69 & 0.57 & 0.62 & $\underline{\mathrm{NG}}$ \\
\hline & 2 & 1.81 & 0.80 & 1.10 & 0.95 & 0.96 & 1.30 & $\mathrm{OK}$ \\
\hline & 1 & 1.19 & 0.80 & 0.95 & 0.95 & 0.83 & 1.12 & OK \\
\hline
\end{tabular}

The codes in the table are based on the references [9].

Aging index T: 0.927 , Criteria: Iso $=0.60<\mathrm{Is}, \mathrm{C}_{\mathrm{TU}} \bullet \mathrm{S}_{\mathrm{D}}>0.30$. 
present seismic evaluation standard. In spite of this, the 3rd floor and the penthouse are strong due to their small area and many walls. However, the position of the penthouse (4th to 6th floors) has a planar eccentricity against the plane arrangement of the 3rd floor. Therefore, the Is value fell below the standard value $(=0.6)$ due to the eccentricity ratio of the 3 rd floor of 0.359 in the $\mathrm{X}$ direction; 0.241 in the $\mathrm{Y}$ direction.

\section{Seismic reinforcement plan and seismic capacity}

From the results described in Section 6, the reinforcement plan was made to increase the bearing force in the $\mathrm{X}$ direction on the 3rd floor, and solve the eccentricity ratio caused by the penthouse in the $\mathrm{Y}$ direction. To solve the eccentricity ratio, the seismic reinforcement plan took into account that the building is a historical landmark, and increased concrete of the interior walls to increase the strength and reduce the eccentricity ratio, not providing slits to the walls so that the appearance of the building would not be affected. Figure 10 shows the details of the reinforcement plan.

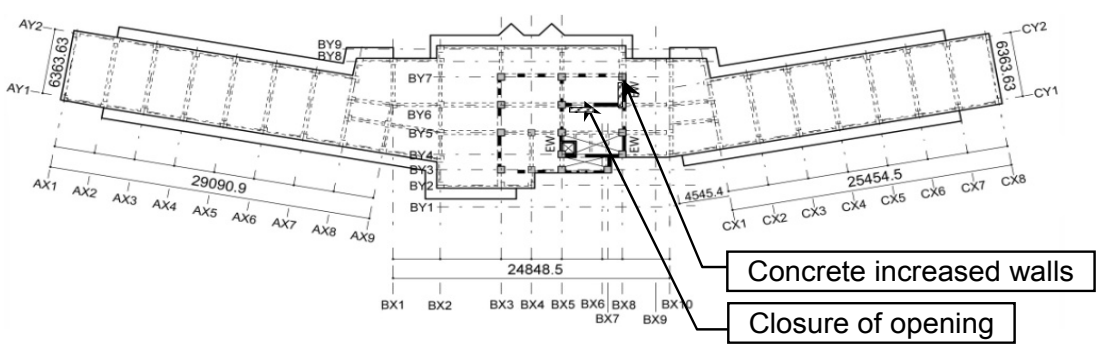

Figure 10: Seismic reinforcement location chart (3rd floor framing plan).

Table 9: $\quad$ Seismic evaluation results (after reinforcement).

\begin{tabular}{|c|c|c|c|c|c|c|c|c|}
\hline & Floor & $\mathrm{C}$ & $\mathrm{F}$ & $\mathrm{E}_{0}$ & $\mathrm{~S}_{\mathrm{D}}$ & $\mathrm{I}_{\mathrm{S}}$ & $\mathrm{C}_{\mathrm{TU}}, \mathrm{S}_{\mathrm{D}}$ & Evaluation \\
\hline \multirow{7}{*}{$\begin{array}{c}\mathrm{X} \\
\text { direction }\end{array}$} & 6 (PH3) & 6.03 & 1.00 & 1.61 & 0.95 & 1.42 & 1.53 & $\mathrm{OK}$ \\
\hline & 5 (PH2) & 5.10 & 1.00 & 1.79 & 0.95 & 1.57 & 1.70 & $\mathrm{OK}$ \\
\hline & 4 (PH1) & 2.33 & 1.00 & 0.95 & 0.95 & 0.83 & 0.90 & $\mathrm{OK}$ \\
\hline & 3 & 2.18 & 1.00 & 1.11 & 0.63 & 0.65 & 0.70 & OK \\
\hline & 2 & 2.41 & 1.00 & 1.82 & 0.95 & 1.61 & 1.73 & $\mathrm{OK}$ \\
\hline & 1 & 1.58 & 1.00 & 1.58 & 0.95 & 1.39 & 1.50 & $\mathrm{OK}$ \\
\hline & Floor & $\mathrm{C}$ & $\mathrm{F}$ & $\mathrm{E}_{0}$ & $\mathrm{~S}_{\mathrm{D}}$ & $\mathrm{I}_{\mathrm{S}}$ & $\mathrm{C}_{\mathrm{TU}}, \mathrm{S}_{\mathrm{D}}$ & Evaluation \\
\hline \multirow{6}{*}{$\begin{array}{c}\mathrm{Y} \\
\text { direction }\end{array}$} & $6(\mathrm{PH} 3)$ & 5.18 & 1.00 & 1.38 & 0.95 & 1.22 & 1.31 & $\mathrm{OK}$ \\
\hline & $5(\mathrm{PH} 2)$ & 5.56 & 1.00 & 1.95 & 0.95 & 1.72 & 1.85 & $\mathrm{OK}$ \\
\hline & 4 (PH1) & 3.24 & 1.00 & 1.32 & 0.95 & 1.16 & 1.25 & $\mathrm{OK}$ \\
\hline & 3 & 1.77 & 1.00 & 0.90 & 0.78 & 0.65 & 0.70 & $\mathrm{OK}$ \\
\hline & 2 & 1.81 & 0.80 & 1.10 & 0.95 & 0.96 & 1.30 & $\mathrm{OK}$ \\
\hline & 1 & 1.19 & 0.80 & 0.94 & 0.95 & 0.83 & 1.12 & OK \\
\hline
\end{tabular}

The codes, the aging indices, and the criteria in the table are the same as those of Table 8. 
The plan increased the bearing force in the $\mathrm{X}$ direction and improved mainly the $\mathrm{S}_{\mathrm{D}}$ index in the $\mathrm{Y}$ direction. Consequently, Is and $\mathrm{C}_{\mathrm{TU}} \cdot \mathrm{S}_{\mathrm{D}}$ satisfied the criteria values on all the floors. Table 9 shows the calculation results after the reinforcement plan was implemented.

\section{Conclusion}

This paper reported the seismic capacity of a building for disaster reconstruction which was designed and constructed soon after the 1923 Great Kanto Earthquake at the end of Taisho period as an example.

Yoshikazu Uchida, a concrete architectural engineer, made a great contribution to this building. The building shows his design purpose for constructing a building which is highly rigid and can endure a great earthquake in response to the damages caused the 1923 Great Kanto Earthquake. Since the concrete is strong, it is estimated that the building was constructed carefully. From the drawings used during the design and photos during construction, the authors learned exemplary bar arrangement methods before the standards including the Architectural Institute of Japan were created.

\section{References}

[1] Outline of the construction work of Yokufu-en; Yokufukai, "Materials on Yoshikazu Uchida" stored at Tokyo Metropolitan Archives, April 1927

[2] Urban Building Law, 1920; revised in 1924

[3] Reinforcing steel concrete standard specification; Standard for Structural Calculation of Reinforced Concrete Structures, Architectural Institute of Japan, 1933

[4] Doi, M., Second report on concrete strength test (lecture on comprehensive construction material survey, Journal of Architecture and Building Science, 1921

[5] Takahashi, Nakane, Kubota, Nagai, Study on strength control of structural concrete, Part 16: Actual condition and examination of core strength of each member in long-age concrete, Summaries of Technical Papers of Annual Meeting Architectural Institute of Japan, 1980

[6] Tomosawa, Masuda, Ko, Abe, Tanaka, Yasuda, An Experiment on Strength Development of Concrete under Various temperature and Curing Conditions, Summaries of Technical Papers of Annual Meeting Architectural Institute of Japan, 1985

[7] Izumi, I., Maeda, T., Kita, T., Concrete structure durability series: neutralization, Gihodo Shuppan, 1986

[8] Kimura, K., Concrete strength and durability of RC constructions, Kajima Institute Publishing, 1981

[9] Seismic evaluation and seismic reinforcement design manual for existing constructions for Year 2003, Japan Association for Building Research Promotion, 2003 